\title{
KONVERGENSI MEDIA PADA PODCAST RADAR JOGJA DIGITAL DALAM PUBLIKASI BERITA DAN PERLUASAN SEGMENTASI AUDIENS
}

\section{MEDIA CONVERGENCE IN RADAR JOGJA DIGITAL PODCAST IN NEWS PUBLICATION AND AUDIENCE SEGMENTATION EXPANSION}

\author{
Diyah Ayu Karunianingsih \\ Sekolah Tinggi Multi Media "MMTC” Yogyakarta \\ Jalan Magelang km.6 Yogyakarta \\ diya001@kominfo.go.id \\ Diterima tgl. 23/11/2020; Direvisi tgl. 05/05/2021 Disetujui tgl. 20/05/2021
}

\begin{abstract}
The new media wave is considered to be the scourge of destroying the printed mass media. However, the mediamorphosis carried out by the print media has actually opened up opportunities to survive by making media coverages utilizing multiplatform. Currently the trend of podcast enthusiasts continues to increase. Research attempts to prove that podcast is open up space for mass media to become an alternative broadcasting model for the future that can not only be utilized by broadcast media but also printed media. The research was conducted to find the media convergence model carried out by the Radar Jogja Digital podcast, and to analyze the audience segmentation expansion strategy through the Radar Jogja Digital podcast. Radar Jogja as a printed media performs mediamorphosis and media convergence, one of which is the podcast. The object of research is Radar Jogja Digital Podcast. This research is a descriptive qualitative study with a phenomenological method. The results of the study found that the Radar Jogja Digital podcast have implemented three types of journalistic convergence, including newsroom convergence, news gathering convergence, and content convergence and also implemented continuum convergence, in the form of crosspromotion, cloning, coopetition, content sharing, but it hasn't fully implemented full coverage. The development of the Radar Jogja Digital podcast is a strategy to expand the audience segmentation targeting the millennial generation.
\end{abstract}

Keywords: Mediamorphosis, Media Convergence, Podcast, Audience Segmentation

\begin{abstract}
ABSTRAK
Gelombang media baru dianggap menjadi momok penggerus media massa cetak. Namun, mediamorfosis yang dilakukan media cetak justru membuka peluang untuk bertahan dengan melakukan kovergensi media memanfaatkan multiplatform. Saat ini tren peminat podcast terus meningkat. Penelitian berusaha meneliti bahwa podcast membuka ruang bagi media massa untuk menjadi model penyiaran alternatif masa depan yang tidak hanya dapat dimanfaatkan oleh media penyiaran, tetapi juga media massa cetak. Radar Jogja sebagai media cetak melakukan mediamorfosis dan konvergensi media salah satunya pada podcast. Objek penelitian adalah podcast Radar Jogja Digital. Penelitian berusaha menemukan model konvergensi media yang dilakukan podcast Radar Jogja Digital, dan menganalisis strategi perluasan segmentasi audiens pada podcast Radar Jogja Digital. Penelitian deskriptif kualitatif dengan metode fenomenologi. Hasil penelitian menemukan bahwa podcast Radar Jogja Digital menerapkan tiga jenis konvergensi jurnalistik meliputi konvergensi newsroom, konvergensi news gathering, dan konvergensi konten. Selain itu, juga menerapkan konvergensi kontinum yang meliputi cross-promotion, cloning, coopetition, content sharing, sedangkan full coverage belum sepenuhnya diterapkan. Pengembangan podcast Radar Jogja Digital merupakan strategi perluasan segmentasi audiens Radar Jogja dengan sasaran generasi milenial.
\end{abstract}

Kata Kunci: Mediamorfosis, Konvergensi Media, Podcast, Segmentasi Audiens

\section{PENDAHULUAN}

Tahun 2007 bisnis koran The Sun Inggris milik Rupert Murdoch jatuh. Hal ini diikuti sejumlah media cetak di Amerika Serikat termasuk Newsweek yang sudah 8 tahun menguasai pemberitaan di Amerika Serikat. Newsweek resmi menamatkan riwayat di bisnis media cetak pada tanggal 31 Desember 2012. Sehari berikutnya menyatakan resmi beralih menjadi media online (Rahmad, 
2013). Konsultan teknologi informasi dari Massachusetts, Paul Gillin dalam (Rahmad, 2013) mengatakan perkembangan ekonomi bergerak melawan bisnis cetak. Media cetak melibatkan banyak karyawan sehingga biaya produksi lebih mahal dari media online. Selain itu zaman sekarang generasi muda lebih menyukai bermain internet daripada membeli majalah dan koran. Menurut Rupert Murdoch, umur media cetak dapat diperpanjang jika media cetak menghentikan arogansinya, dan memberikan perhatian terhadap kebutuhan masyarakat terutama anak muda (Rahmad, 2013). Philip Meyer dalam (Rahmad, 2013) meramalkan pada tahun 2044 hanya akan ada satu eksemplar koran.

Nasib media cetak di Indonesia hampir sama. Catatan akhir tahun Aliansi Jurnalis Independen (AJI) dikutip dari (Permana, 2017) menyebut bahwa tahun 2015 sebagai musim gugur media di Indonesia. Hal ini mengacu data Nielsen bahwa dari 117 surat kabar ada 16 media telah gulung tikar pada tahun 2015. Begitu pula majalah, dari 170 majalah hanya tersisa 132 majalah. Sejumlah media yaitu Sinar Harapan, Harian Bola, dan Jakarta Globe menyatakan tutup karena tidak mampu bertahan di industri media cetak akibat gempuran media online (Prihartono, 2016). Sementara (Kusuma, 2016) menyebutkan perkembangan internet yang sangat pesat mendorong masyarakat untuk mengakses media online secara mudah. Sementara itu media cetak mulai terancam keberadaannya karena masyarakat beralih ke media online. Media konvensional termasuk media cetak harus mampu mempertahankan kredibilitas dan kepercayaan terhadap informasi yang disajikan agar tetap bertahan. Industri media cetak harus melakukan perubahan, salah satunya perubahan strategi. Media cetak harus mampu mendefinisikan dirinya dari mediumnya, tidak hanya sekedar kertas. Kekuatan dan nilainya tidak hanya datang pada kontrol konten dan distribusinya, namun strategi lain dengan mengintegrasikan konten koran ke dalam media online (Kusuma, 2016).

Surat kabar harian Bernas merupakan media cetak lokal di Yogyakarta, yang turut tumbang. Koran Bernas resmi tidak beroperasi sejak 1 Maret 2018 setelah berusia 72 tahun. Koran Bernas didirikan pada tahun 1946 dan telah hidup selama empat zaman. Direktur Utama PT. Media Bernas Jogja, Putu Putrayasa mengatakan keputusan tutupnya koran Bernas karena di satu sisi biaya produksi terus meningkat, sementara di sisi lain jumlah pembaca dan pendapatan iklan stagnan bahkan cenderung menurun (Kurniawan, 2018). Manajer sirkulasi koran Bernas, Tedy Kartiyadi mengatakan pesatnya perkembangan teknologi informasi melahirkan media online dan media sosial. Media cetak seperti Bernas juga terdampak mulai dari jumlah pembaca yang menurun hingga pendapatan iklan merosot drastis. Menurut Tedy, kini masyarakat lebih suka membaca media online dan media sosial daripada media cetak. Begitu pula pemasang iklan lebih memilih beriklan di media sosial secara gratis daripada media cetak (M. A. Hidayat, 2018). Tumbangnya koran Bernas menjadi gambaran dampak media online terhadap media massa cetak di Yogyakarta.

Sementara media elektronik seperti televisi, meski saat ini televisi masih mendominasi konsumsi media, namun jika dilihat dari durasi waktu yang dihabiskan konsumen untuk menonton televisi tidak mengalami pertumbuhan dalam 3 tahun terakhir. Data Nielsen Consumer \& Media View (CMV) pada kuartal pertama 2016, konsumen di sebelas kota di Indonesia menghabiskan waktu rata-rata 4 jam 54 menit dalam satu hari untuk menonton televisi. Pada kuartal yang sama di tahun 2019 menghabiskan waktu sekitar 4 jam 59 menit. Sementara waktu yang dihabiskan masyarakat untuk mengonsumsi internet justru meningkat dalam 3 tahun terakhir yaitu dari 2 jam 26 menit per hari pada kuartal pertama 2016 menjadi 3 jam 20 menit per hari pada kuartal yang sama tahun 2019. Jelas bahwa media digital mulai mengejar televisi, sehingga dipandang sebagai pendatang baru yang seksi dalam media mix (nielson.com, 2019). 
Data penetrasi pengguna internet di Indonesia tahun 2018 hasil survei nasional yang dilakukan Asosiasi Penyelenggara Jasa Internet Indonesia (APJII) menunjukkan 64,8 persen atau sebanyak 171,17 juta jiwa dari total populasi penduduk Indonesia sebanyak 265,16 juta orang. Jumlah ini menunjukkan adanya peningkatan bila dibanding penetrasi pengguna internet tahun 2017 yaitu 54,68 persen atau sebanyak 143,26 juta jiwa dari total populasi penduduk Indonesia 262 juta orang. Usia pengguna internet banyak pada usia 15-39 tahun. Ditinjau dari perangkat yang paling banyak digunakan untuk mengakses internet setiap hari yaitu telepon pintar sebesar 93,9 persen (APJII, 2019). Senada dengan data Nielsen Consumer \& Media View (CMV) Desember 2019 menunjukkan bahwa di Indonesia, pertumbuhan kepemilikan telepon pintar dalam 5 tahun terakhir (2014-2019) mencapai 250 persen (nielson.com, 2019). Data peningkatan penetrasi pengguna internet tersebut menunjukkan beralihnya konsumsi masyarakat dari media konvensional ke media baru, dan mayoritas masyarakat mengakses internet menggunakan telepon pintar yang karakternya lebih dekat dengan masing-masing individu. Era digital saat ini, konsumen menjalani 'seamless lifestyle' atau tidak lagi memisahkan aktifitas online dan offline.

Jika media cetak hanya menyuguhkan teks dan foto, media radio menyuguh audio, dan media televisi menyuguhkan media audio visual, maka media baru dapat menyuguhkan konten multimedia, baik teks, foto, grafik, audio, maupun video. Kondisi ini membuat banyak media cetak yang tidak ingin terlindas oleh media baru akhirnya memutuskan ikut bergelut mencari pasar konsumen memanfaatkan media baru dengan melakukan mediamorfosis. Berbagai platform digunakan untuk publikasi konten sebagai implikasi konvergensi media diantaranya website, media sosial, youtube bahkan podcast yang kini terus berkembang dan makin banyak diminati.

Jan Van Djik dalam (Nasrullah, 2016) mengatakan munculnya media baru juga ditandai dengan konvergensi media. Secara struktural, konvergensi media berarti integrasi dari tiga aspek yaitu telekomunikasi, data komunikasi, dan komunikasi massa dalam satu medium (Nasrullah, 2016). Henry Jenkins dalam (Wahyuningsih \& Zulhazmi, 2020) menjelaskan tentang konvergensi media yang mencakup tiga hal yaitu: konvergensi sebagai aliran konten pada berbagai platform media, kerjasama antara beberapa media industri, dan perilaku bermigrasi dari khalayak media.

Perkembangkan teknologi mendesak media massa melakukan mediamorfosis. Munculnya media baru menawarkan cara berkomunikasi baru dengan memanfaatkan media online. Ketika sebuah bentuk media baru muncul, maka media terdahulu akan beradaptasi dan terus berkembang, bukan mati, hal ini disebut Roger Fidler sebagai mediamorfosis (Asyir \& Nurbaya, 2019). Salah satu ciri mediamorfosis adalah adanya konvergensi media.

Dalam perkembangannya di Indonesia, fenomena mediamorfosis dilakukan oleh media konvensional dalam wajah baru dengan memanfaatkan media baru termasuk mediamorfosis yang dilakukan oleh media massa cetak, salah satunya koran harian Radar Jogja. Pembahasan dalam tulisan ini difokuskan pada konvergensi media pada podcast Radar Jogja Digital sebagai media publikasi berita dan perluasan segmentasi audiens yaitu konsumen generasi muda. Penelitian ini untuk mengetahui apakah kehadiran media baru akan menjadi ancaman atau menjadi medium yang akan melengkapi kehadiran media konvensional.

\subsection{Konvergensi Media sebagai Bentuk Mediamorfosis}

Konvergensi media menurut Tery Flow dalam (Wahyuningsih \& Zulhazmi, 2020) merupakan hasil irisan tiga unsur media baru yaitu: jaringan komunikasi (communication), teknologi informasi (computing) dan konten media (content). Sedangkan menurut Preston dalam (Prihartono, 2016) Konvergensi media merupakan konsep penyatuan berbagai layanan informasi dalam satu piranti informasi yang membuat satu gebrakan digitalisasi dan tidak dapat dibendung arus informasinya. 
Konvergensi menyebabkan perubahan radikal dalam penanganan, penyediaan, distribusi, dan pemrosesan seluruh bentuk informasi baik visual, audio, data, dan sebagainya (Prihartono, 2016).

Menurut (Fidler, 2003), terjadinya konvergensi media didukung oleh berbagai hal seperti: kekuatan-kekuatan ekonomi, politik, dan sosial yang memainkan peran besar dalam penciptaaan teknologi-teknologi baru; berbagai penemuan dan inovasi tidak diadopsi secara luas lantaran keterbatasan teknologi itu sendiri; dan adanya kesempatan dan alasan ekonomi, sosial, dan politik yang mendorong perkembangan teknologi baru. Konvergensi industri media dan teknologi digital mengarah pada bentuk-bentuk yang dikenal sebagai komunikasi multimedia. Multimedia atau dikenal sebagai media campuran, pada umumnya didefinisikan sebagai medium yang mengintegrasikan dua bentuk komunikasi atau lebih (Fidler, 2003). Fidler menyatakan kehadiran konvergensi media sebagai salah satu bentuk mediamorfosis yaitu suatu transformasi media komunikasi yang biasanya ditimbulkan akibat hubungan timbal balik yang rumit antara berbagai kebutuhan yang dirasakan, tekanan persaingan dan politik, serta berbagai inovasi sosial dan teknologi. Adopsi teknologi digital oleh perusahaan media massa dalam melahirkan konvergensi media didukung oleh faktor tekanan dalam bisnis media massa. Kini perusahaan media massa berlomba-lomba menganut konvergensi (Fidler, 2003)

Transformasi media cetak ke arah konvergensi dapat mengadopsi jenis konvergensi yang dikemukakan oleh Grant dan Wilkinson dalam (Asyir \& Nurbaya, 2019) dikenal dengan konvergensi jurnalistik. Konvergensi jurnalistik mensyaratkan perubahan cara berpikir media tentang berita dan peliputannya, termasuk cara media memproduksi berita dan menyampaikan berita kepada khalayaknya. Namun, praktik konvergensi saat ini dalam (Asyir \& Nurbaya, 2019) masih sebatas pada cara menyampaikan berita melalui platform yang berbeda yaitu media cetak, penyiaran, dan online. Menurut Grant dan Wilkinson, ada tiga model dalam konvergensi jurnalistik yaitu: konvergensi newsroom, konvergensi newsgathering, dan konvergensi konten. Konvergensi newsroom yaitu jurnalis yang berbeda platform, misalnya dari surat kabar, online, dan televisi menyatukan dirinya dalam satu ruang produksi berita. Mereka mengerjakan tugas sesuai dengan platform medianya. Konvergensi newsgathering, seorang jurnalis dituntut mampu mencapai tingkatan multitasking. Seorang jurnalis dituntut dapat melakukan pekerjaan yang dilakukan oleh media dengan platform lain dalam satu grup. Misalnya, seorang wartawan cetak dituntut mampu membuat berita untuk medium cetak, online, dan sekaligus untuk televisi. Selain itu juga dituntut untuk mengambil foto atau video pada saat peliputan. Sedangkan konvergensi konten, berita akhirnya disuguhkan dalam bentuk multimedia, yang merupakan kombinasi antara teks, gambar/foto, audio, video, podcast, atau penyajian yang lain.

Dailey, Demo dan Spillman dikutip dari (Wahyuningsih \& Zulhazmi, 2020) mendefinisikan lima tahapan konvergensi media berdasarkan tingkat partisipasinya yang disebut konvergensi kontinum (continuum convergence). Konvergensi kontinum adalah model konvergensi yang memiliki fungsi sebagai instrument untuk mendefinisikan dan mengevaluasi tahapan proses konvergensi yang terjadi dalam suatu ruang berita dan bukan bertujuan untuk menilai keberhasilan suatu ruang berita (Wahyuningsih \& Zulhazmi, 2020). Lima tahapan konvergensi kontinum yaitu: 1) Cross-Promotion, tahap proses penggunaan kata-kata atau elemen gambar untuk mempromosikan atau mengenalkan konten media yang diproduksi, untuk dimunculkan ke platform lain. Biasanya cross promotion dilakukan dengan mempublikasikan secara visual atau menampilkan logo secara teratur. Bentuk cross promosion dapat dilakukan dengan mengenalkan konten antar platform secara verbal dan mengadakan pertemuan untuk mendiskusikan konten yang akan dipromosikan pada tiap platform; 2) Cloning, tahap ketika konten media dimuat ulang pada platform lain baik melalui proses editing maupun tanpa ediring. Cloning dapat diartikan bahwa satu media dapat menampilkan konten berita dari ruang berita media lain dengan atau tanpa perubahan; 
3) Competition, tahap ketika entitas media yang terkonvergensi saling bekerjasama dan berkompetisi disaat yang bersamaan atau kolaborasi. Pada tahap ini ditandai adanya aktivitas yang mencerminkan bahwa para anggota dari tiap platform tetap berkompetisi dengan platform lainnya. Pada tahap ini, kedua anggota staf harus menjalankan sifat kooperatif dan kompetitif secara bersamaan; 4) Content sharing, tahap yang ditandai dengan adanya pertemuan secara rutin untuk bertukar ide dan tema oleh masing-masing anggota dan mendistribusikannya ke tiap platform. Selain itu saling memberikan feedback atau merencanakan projek khusus bersama dan membagi biaya proyek khusus; 5) Full convergence, yaitu tahapan konvergensi ketika masing-masing platform telah memiliki editor atau manajer untuk mengelola pembagian proses perencanaan berita (story planning). Memperbolehkan manajer bersama untuk menentukan kekuatan masing-masing media yang digunakan untuk memberikan cerita yang paling bermakna bagi penonton dan membetuk tim yang terdiri dari anggota tiap platform untuk meliput berita dan mengolahnya. Pada tahap full coverage, media bekerja sama menghasilkan konten dan topik secara kolaboratif dengan memanfaatkan kekuatan platform media masing-masing.

Meskipun telah terjadi perdebatan panjang yang menganggap kehadiran media baru akan menjadi ancaman bagi eksistensi media konvensional yang berbasis tunggal seperti media cetak (majalah dan surat kabar), media radio (audio) dan media televisi (video), namun sejumlah pendapat menyebut kehadiran media baru justru menjadi medium yang akan melengkapi kehadiran media konvensional. Hingga akhir tahun 1990-an beberapa ahli seperti McQuail dan Livingstone masih menyebut internet sebagai penambahan, bukan penggantian bagi media konvensional (Fadilah et al., 2017). Oleh karena itu, dalam tulisan ini menganalisis konvergensi media yang dilakukan Radar Jogja Digital difokuskan pada podcast Radar Jogja Digital menggunakan teori konvergensi jurnalistik yang dikemukakan Grant dan Wilkinson serta konvergensi kontinum yang dikemukakan Dailey, Demo dan Spillman.

\subsection{Podcast dan Potensi sebagai Media Siaran}

Podcast merupakan salah satu implikasi mediamorfosis. Sejarah awal kemunculan podcast tercatat tahun 2004. Ben Hammersley dalam (Geoghegan \& Klass, 2007) menyebut kata "podcasting" dalam artikelnya pada www.theguardian.com yang membahas audioblog dan radio online. Hampir 7 bulan berikutnya istilah "podcasting" seolah tenggelam sampai akhirnya beberapa orang menggunakannya sebagai nama pada saat mendaftarkan nama domain, seperti yang dilakukan Dannie Gregorie yang mendaftarkan domain podcaster.net. Catatan lain dalam (Zaenudin, 2017) menyebutkan bahwa sejarah podcast lahir seiring kelahiran iPod produksi Apple pada tahun 2001 yang diperkenalkan oleh Steve Jobs. Podcast dapat dikatakan "iPod broadcasting" atau siaran dengan menggunakan iPod. Berbeda dengan radio FM/AM konvensional, podcast tidak menyiarankan siarannya secara linear. Podcast yang serupa dengan youtube merupakan platform siaran suara on demand.

Disebutkan dalam catatan lain yang dikutip dari (Fadilah et al., 2017) bahwa podcast audio telah berkembang sejak tahun 2005, ketika Apple menambahkan materi podcast pada iTunes dengan tema-tema terbatas. Istilah podcast awalnya identik dengan materi berformat audio. Selanjutnya materi podcast makin berkembang dan beragam. Kemasannya berupa sandiwara/drama, dialog/talkshow, monolog dan feature/dokumenter, dengan rentang topik sangat luas seperti sejarah, ilmu pengetahuan, politik, ekonomi, filsafat dan topik lain. Disebutkan pula bahwa menurut www.time.com beberapa program podcast mampu menyamai popularitas drama televisi (Fadilah et al., 2017). 
Menurut Merriam Webster yang dikutip dari (Hennig, 2017), podcast didefinisikan sebagai suatu program (seperti musik atau pembicaraan) yang tersedia dalam format digital, untuk pengunduhan otomatis melalui internet sebagai file audio yang dilampirkan ke umpan RSS. Istilah ini mulai digunakan ketika iPod sedang popular. Pada saat itu teknologi dikembangkan untuk memungkinkan berlangganan feed dengan tautan ke file audio yang dapat diunduh. Podcast menggunakan perangkat lunak untuk berlangganan dan secara otomatis diberitahu ketika episode baru tersedia. Karena bandwidth untuk kebanyakan orang terbatas, maka mengunduh file untuk mendengarkan secara offline sangat berguna. Hal ini menjadi salah satu kelebihan podcast. Dalam perkembangannya, podcast juga mengacu pada materi dalam bentuk video, sehingga jenis podcast berupa podcast audio dan podcast video. Apple membatasi podcast sebagai siaran audio atau siaran video yang tersedia di internet untuk diputarkan pada perangkat portabel dan komputer, seperti iPad, iPod atau Mac (Fadilah et al., 2017). Podcasting dikutip dari (Geoghegan \& Klass, 2007) merupakan teknologi perkembangan media yang memungkinkan siapa saja dapat terlibat, mengekspresikan diri, bertukar ide, atau mempublikasikan produk podcast mereka. Podcasting menempatkan kekuatan untuk berkomunikasi ke tangan individu, tanpa sebuah sistem dan aturan dapat menjangkau khalayak yang lebih beragam secara geografis dari pada stasiun radio dengan pemancar AM/FM, tanpa pemancar, tanpa satelit, dan tanpa peraturan. Hal tersebut juga menjadi kelebihan podcast. Kelebihan podcast yang lain adalah flexible, yaitu konsumen dapat memilih menu atau topik sesuai keinginan (on demand) yang dapat dinikmati kapanpun dan dimanapun. Artinya tidak tergantung jam siar seperti mendengarkan radio atau menonton televisi, namun dapat dinikmati sambil melakukan aktivitas lain.

Popularitas pengguna podcast secara global cenderung meningkat. Data persentase masyarakat Amerika yang mendengarkan podcast meningkat secara substansial selama dekade terakhir. Menurut Edison Research dan data survei Triton Digital, pada tahun 2019, lima puluh satu persen orang Amerika berusia 12 tahun atau lebih pernah mendengarkan podcast, dan tiga puluh dua persen telah mendengarkan podcast dalam sebulan terakhir. Jumlah pendengar podcast naik menjadi dua puluh enam persen pada tahun 2018 dibanding tahun 2008 yang hanya sembilan persen. Selanjutnya, dua puluh dua persen pendengar berusia 12 tahun dan lebih tua mengatakan mereka telah mendengarkan podcast pada minggu lalu, naik dari tujuh persen ketika ini pertama kali diukur pada tahun 2013 (PEW Research Center Journalism \& Media, 2019). Data ini adalah untuk semua jenis podcast dan tidak membagi program berita.

Berbagai kategori podcast terus berkembang, termasuk podcast berita. Berdasar data penelitian Reuters Institute dalam (Newman \& Gallo, 2019) disebutkan bahwa jumlah podcast berita secara global naik hampir 12 ribu antara bulan Januari sampai dengan Oktober 2019. Terjadi peningkatan sekitar sepertiga atau tiga puluh dua persen. Menurut laporan Reuters Institute, acara bincang-bincang dan wawancara adalah sub-genre paling populer di dalam berita, bersama dengan seri narasi satu kali, tetapi berita harian telah menjadi fokus yang semakin penting. Laporan tersebut telah mengidentifikasi hampir enam puluh podcast berita harian di lima negara yang diteliti yaitu Amerika Serikat, Inggris, Australia, Prancis dan Swedia yang sebagian besar telah diluncurkan dalam 8 bulan terakhir. Beberapa podcast berita paling populer di Amerika Serikat seperti The Daily dari New York Times berhasil menarik minat jutaan pendengar sementara yang lain berjuang di pasar yang semakin kompetitif. Laporan tersebut menunjukkan bahwa penerbit melakukan investasi besar dalam podcasting berita dengan harapan dapat menarik segmentasi audiens yang lebih muda, membangun kebiasaan, dan mendatangkan pendapatan tambahan. 
Newman and Gallo menyebut podcasting berita adalah titik terang yang langka untuk industri berita (Newman \& Gallo, 2019).

Melihat kondisi di Indonesia, Spotify's Head of Studios for Southeast Asia, Carl Zuzarte mengatakan bahwa Indonesia adalah salah satu negara dengan pasar podcast yang berkembang pesat. Lebih dari dua puluh persen pengguna Spotify di Indonesia mendengarkan podcast setiap bulan. Jumlah ini lebih tinggi dari rata-rata global. Pendengar di Indonesia mendengarkan podcast di Spotify lebih sering dibandingkan negara lain di Asia Tenggara (A. Hidayat, 2020). Artinya di Indonesia juga memiliki potensi besar bagi industri media untuk ikut bersaing menarik konsumen dengan menyuguhkan berita atau konten lain menggunakan podcast. Bukan hanya radio atau televisi yang ikut bersaing menyuguhkan podcast, namun dengan media baru ini justru membuka lebar peluang bagi media cetak untuk ikut bersaing memanfaatkan podcast sebagai media publikasi berita.

Penelitian tentang konvergensi media dan podcast pernah dilakukan oleh (Fadilah et al., 2017), menjelaskan bahwa podcast menjadi media yang sangat potensial untuk berkembang mengikuti perubahan perilaku pendengar khususnya dalam mengonsumsi konten audio. Fokus penelitian adalah podcast sebagai alternatif distribusi konten audio. Penelitian difokuskan pada strategi optimalisasi podcast audio mencakup pengembangan bahan podcast, pendekatan dan distribusi konten yang sesuai dengan kebutuhan, keinginan, cara khalayak mengonsumsi konten audio, serta kesesuaian konten dengan karakter dan orientasi media (Fadilah et al., 2017). Podcast yang dianalisis bersifat umum, bukan spesifik berita dari media massa berita.

Penelitian juga dilakukan oleh Meisyanti dan Kencana yang memfokuskan penelitian tentang perkembangan podcast sebagai siaran on demand, dengan meninjau beberapa podcast pribadi. Penelitian dilakukan dengan membandingkan antara siaran radio berdasar karakter siaran radio dan podcast sebagai siaran on demand (Meisyanti \& Kencana, 2020). Sementara (Wahyuningsih \& Zulhazmi, 2020) meskipun penelitian dilakukan di Radar Jogja dengan fokus penelitian mengenai penerapan konvergensi jurnalistik dan konvergensi kontinum namun penelitian dilakukan secara menyeluruh bukan terfokus pada podcast Radar Jogja Digital.

Surat kabar harian Radar Jogja merupakan suplemen dari harian Jawa Pos Group yang memiliki market share atau wilayah edar di daerah Yogyakarta dan sekitarnya. Radar Jogja merupakan media cetak di Yogyakarta yang bernaung di bawah induk perusahaan Jawa Pos Group. Dominasi media online memaksa surat kabar harian Radar Jogja untuk menyusun strategi demi mempertahankan eksistensinya, yaitu dengan membuat media online berupa situs berita radarjogja.co namun untuk portal berita kini mengikuti atau menjadi satu dengan portal berita Jawa Pos dalam website radarjogja.jawapos.com. Selain situs berita, Radar Jogja juga memiliki kanal youtube Radar Jogja Channel, media sosial instagram, Facebook, twitter, dan sejak 2018 mulai mempublikasikan podcast dengan nama podcast Radar Jogja Digital.

Produksi konten terus dilakukan dan dipublikasikan hingga saat ini dengan konten yang makin bervariasi diantaranya podcast News, Bias, Story, Mainbola, Lifestyle, Cerita Misteri, dan mengulas film (film review). Poscast Radar Jogja Digital dapat dikonsumsi melalui sejumlah platform yaitu Anchors, Spotify, Google Podcast, Apple Podcast dan Radio Public. Perkembangan podcast Radar Jogja Digital yang cukup pesat membuat peneliti tertarik melakukan penelitian tentang konvergensi media yang dilakukan Radar Jogja Digital dalam menggunakan podcast untuk publikasi berita dan perluasan segmentasi audiens.

Penelitian difokuskan pada konvergensi media pada podcast Radar Jogja Digital sebagai publikasi berita dan upaya perluasan segmentasi audiens. Hal ini penting dilakukan mengingat tren 
pengguna podcast secara global termasuk di Indonesia terus meningkat, dan ini menjadi peluang besar bagi media cetak untuk ikut meramaikan dunia penyiaran menggunakan podcast sebagai realitas mediamorfosis akibat pesatnya kemajuan teknologi. Podcast menjadi peluang model media penyiaran masa depan yang tidak hanya dimanfaatkan bagi media radio atau televisi saja, namun juga bagi media cetak. Hal ini sejalan dengan Ben Hammersley (British journalist and British Internet Technolog) yang mengatakan penyiaran berubah dalam ledakan podcast yang mencakup sejumlah bakat besar, dari penyiar profesional hingga penggemar yang menawarkan wawasan tentang apapun, bahkan podcasting telah membawa orang ke dunia penyiaran yang biasanya tidak akan pernah melihat bagian dalam studio rekaman. Hal itu berubah bukan hanya cara orang mendengarkan audio, namun cara industri penyiaran bekerja (Robertson, 2019).

\section{METODE PENELITIAN}

Pendekatan yang digunakan dalam penelitian ini adalah deskriptif kualitatif dengan metode penelitian fenomenologi. Penelitian kualitatif digunakan untuk meneliti objek alamiah, dimana peneliti merupakan instrumen kunci. Dalam penelitian ini teknik pengumpulan data dilakukan secara gabungan, sementara analisis data bersifat induktif, dan hasil penelitian kualitatif lebih menekankan makna daripada generalisasi (Sugiyono, 2006).

Wacana fenomenologi harus dapat memberikan deskripsi setepat mungkin tentang apa yang hadir dan ada di hadapan kesadaran. Bagi Husserl dikutip dari (Madjid, 2014), fenomena adalah realitas yang sesungguhnya dengan semboyan "zuruck zu den sachen selbst". Objek dalam fenomena adalah objek yang sesuai dengan pemahaman subjek. Kesadaran bukanlah sesuatu yang imanen tetapi bersifat intensional karena selalu merupakan 'kesadaran akan sesuatu', jadi bukan kesadaran tanpa arah tujuan (Madjid, 2014). Fenomenologi untuk mengetahui fenomena yang terjadi di masyarakat dalam hal ini untuk memahami fenomena mediamorfosis yang dilakukan media massa cetak dengan melakukan konvergensi media untuk mempertahankan eksistensi medianya dalam hal ini Radar Jogja. Hal ini digunakan untuk menganalisis model konvergensi yang dilakukan media cetak dan memahami gambaran media online dalam hal ini podcast yang dapat menjadi media alternatif penyiaran di masa depan.

Teknik pengumpulan data untuk memahami fenomena mediamorfosis yang dilakukan media cetak adalah wawancara dan observasi. Wawancara dilakukan kepada Online Manager Radar Jogja Digital yang sekaligus Pemimpin Redaksi Radar Jogja Digital dan host podcast Radar Jogja Digital. Peneliti menganggap Online Manager Radar Jogja Digital yang sekaligus Pemimpin Redaksi Radar Jogja Digital dan host Podcast Radar Jogja Digital memahami informasi baik terkait kebijakan konvergensi media dan pengembangan podcast Radar Jogja Digital. Wawancara juga dilakukan kepada Creative and Production Leader di Media Online Radar Jogja Digital, karena menurut peneliti informan ini memahami mengenai rencana dan strategi pengembangan Radar Jogja Digital sebagai media online termasuk pengembangan podcast Radar Jogja Digital serta target sasaran audiens. Teknik pengumpulan data observasi dengan melakukan pengamatan langsung terhadap objek penelitian yaitu podcast Radar Jogja Digital dan proses produksinya sampai pada publikasi konten. Hasil pengumpulan data pada penelitian ini adalah data deskriptif berupa kata tertulis, atau lisan orang-orang atau perilaku yang diamati (Moleong, 2004).

Triangulasi data hasil wawancara dengan subjek penelitian, dilakukan dengan pengamatan terhadap beberapa platform yaitu podcast Radar Jogja Digital, kanal Youtube Radar Jogja Channel, media sosial instagram, Facebook dan twitter Radar Jogja, platform Spotify dan Anchor sebagai platform yang digunakan untuk konvergensi media. Peneliti hanya sebatas mengamati sejumlah 
platform tersebut untuk mengecek data wawancara dengan publikasi konten pada sejumlah platform tersebut, dan tidak melakukan analisis isi/konten secara mendalam. Selanjutnya data dalam penelitian ini dianalisis secara kualitatif, peneliti melakukan aktivitas secara serempak dengan pengumpulan data, interpretasi data dan pelaporan data (Creswell, 2012).

\section{HASIL DAN PEMBAHASAN}

Radar Jogja sebagai bagian dari Jawa Pos telah melakukan mediamorfosis dengan mengembangkan media online yang diberi nama Radar Jogja Digital. Berdasar hasil wawancara dengan Pemimpin Redaksi Radar Jogja Digital, Reren Indranila menyebut bahwa saat ini Radar Jogja memiliki dua media yaitu media surat kabar harian (cetak) yang publikasinya menjadi bagian surat kabar Jawa Pos, dan media online Radar Jogja Digital.

Pada media online Radar Jogja Digital, sejumlah platform dipilih sebagai media publikasi konten berita yaitu portal berita (website berita), kanal youtube, media sosial instagram, Facebook, twitter, dan salah satu platform yang digunakan untuk menyikapi tren konsumsi informasi masyarakat yang kini kian meningkat, yaitu podcast dengan nama podcast Radar Jogja Digital. Reren menyebutkan, Podcast Radar Jogja Digital awalnya menyuguhkan konten berita dengan nama podcast news, namun dalam perkembangannya bukan hanya menjadi media publikasi berita dan talk, namun juga publikasi konten lain yang bersifat hiburan karena banyak pendengar podcast yang menyukai konten hiburan. Hal ini dilakukan untuk mencari pendengar podcast terlebih dulu. Podcast Radar Jogja Digital saat ini (per Agustus 2020) memiliki sejumlah konten yang dapat dikategorikan dalam konten berita dan non berita.

Pengamatan terhadap podcast Radar Jogja Digital yang dilakukan untuk triangulasi data dilakukan oleh peneliti. Apabila dilihat dalam pendekatan kemiripan dengan program radio, maka konten podcast Radar Jogja Digital dapat dikategorikan dalam 2 kategori, yaitu konten berita dan hiburan (non berita). Hal ini seperti yang disampaikan Pemimpin Redaksi sekaligus host podcast Radar Jogja Digital. Konten podcast yang berisi berita dan informasi, meliputi: 1) podcast news, berupa berita hard news yaitu berita-berita headline atau berita harian; 2) podcast bias (bincang asik) yaitu konten podcast yang mengandung nilai informasi dan dikemas dalam bentuk obrolan (bincang-bincang) dengan menghadirkan narasumber; 3) podcast lifestyle berisi informasi seputar gaya hidup yang dikemas dalam bentuk obrolan santai; 4) podcast mainbola adalah podcast yang berisi informasi seputar perkembangan terbaru sepak bola yang dikemas dalam bentuk obrolan.

Sementara konten hiburan yaitu: 1) Podcast cerita misteri yang berisi kisah dan pengalaman misteri; 2) Podcast story yang berisi cerita berlatar belakang tim yang bekerja di Radar Jogja Digital. Sebagai contoh cerita selama bekerja pada saat menjelang lebaran, pada hari lebaran, kisah mudik atau lembur bagi tim peliputan dan lain sebagainya; 3) Podcast tentang film review, biasanya berupa obrolan film yang dilakukan tim Radar Jogja Digital usai menonton salah satu film. Pengkategorian ini sebenarnya belum dilakukan secara jelas dan tegas oleh Pimpinan Redaksi Podcast, namun menjadi pengkategorian yang muncul pada saat wawancara, untuk membedakan podcast yang berisi nilai berita dengan podcast hiburan. Dalam pembahasan ini difokuskan pada podcast yang termasuk dalam kategori podcast berita.

\subsection{Konvergensi Media pada Podcast Radar Jogja Digital}

Dalam perjalanannya, podcast Radar Jogja Digital menerapkan konvergensi media. Berdasar konvergensi jurnalistik yang dikemukakan Grant dan Wilkinson dalam (Asyir \& Nurbaya, 2019) bahwa transformasi media cetak ke arah konvergensi dapat mengadopsi tiga jenis konvergensi 
yaitu konvergensi newsroom, konvergensi news gathering, dan konvergensi konten. Podcast Radar Jogja Digital juga menerapkan konvergensi kontinum yang dikemukakan oleh Dailey, Demo dan Spillman (Wahyuningsih \& Zulhazmi, 2020). Ada lima tahapan konvergensi kontinum meliputi cross-promotion, cloning, coopetition, content sharing dan full convergence, namun belum semua level konvergensi kontinum telah dilaksanakan.

\section{a) Konvergensi Newsroom}

Model konvergensi newsroom pada Podcast Radar Jogja Digital terkonvergensi dengan newsroom portal berita dan newroom redaksi cetak harian Radar Jogja.

"Untuk kebutuhan berita di podcast news kita ambil, bacain berita dari berita di website radarjogja.jawapos.com, berita di website diunggah dari newsroom berita-beritanya redaksi cetak" (wawancara dengan Reren Indranila, Pimred Radar Jogja Digital, 10 Agustus 2020).

Website/portal berita radarjogja.jawapos.com. merupakan salah satu platform publikasi berita dibawah Radar Jogja Online dan Jawa Pos. Newsroom portal berita terkonvergensi dengan newroom redaksi cetak harian Radar Jogja karena mayoritas berita pada website diambil dari newsroom redaksi media cetak harian Radar Jogja. Sementara berita untuk podcast berita diambil dari portal berita radarjogja.jawapos.com.

Reren menambahkan (wawancara 10 Agustus 2020), newsroom (redaksi) Radar Jogja Digital dan Radar Jogja Cetak sebenarnya saat ini sudah terpisah dan memiliki struktur organisasi masingmasing, akan tetapi karena keduanya berada dibawah Radar Jogja, maka untuk kebutuhan berita bagi masing-masing media baik cetak atau online dapat saling mendukung dan melengkapi. Secara teknis, baik Radar Jogja Digital maupun Radar Jogja Cetak (surat kabar harian Radar Jogja) memiliki berita masing-masing, memiliki perencanaan berita dan peliputan sendiri-sendiri untuk kebutuhan masing-masing. Namun disisi lain, saat ini Radar Jogja Digital belum mampu memenuhi kebutuhan berita secara signifikan karena keterbatasan sumber daya manusia yang dimiliki. Oleh karena itu, untuk memenuhi kebutuhan berita setiap harinya, terutama untuk platform portal berita www.radarjogja.jawapos.com, maka Radar Jogja Digital masih menggunakan berita-berita yang ada pada newsroom Radar Jogja cetak.

Berita dari newsroom Radar Jogja cetak diunggah ke portal berita dengan langsung memasukannya pada CMS (Content Management System) yang digunakan. Berita yang diambil dari newsroom Radar Jogja cetak ini sudah dalam bentuk berita jadi, bukan data mentah. Selain newsroom Radar Jogja cetak, Radar Jogja Digital juga dapat mengakses newsroom Jawa Pos (data Jawa Pos skala nasional), namun data berupa data mentah sehingga perlu ditulis sesuai kebutuhan berita Radar Jogja Digital.

Kemudian kaitannya dengan konvergensi newsroom pada Podcast Radar Jogja Digital, Reren mengatakan news podcast yang mempublikasikan berita, diambil dari berita yang diunggah pada portal berita www.radarjogja.jawapos.com. Untuk kebutuhan berita di news podcast, berita diproduksi bukan murni hasil peliputan tim produksi tim produksi podcast, tetapi berita diambil dengan membacakan headline berita yang dipublikasikan di portal berita www.radarjogja.jawapos.com.

"Langkah ini karna kita masih minim sumber daya manusia untuk peliputan, oleh karena itu cara yang paling memungkinkan adalah dengan membacakan berita-berita headline dari portal berita. Selain itu tim peliputan khusus untuk podcast sendiri tidak ada, tetapi menjadi satu dengan tim peliputan Radar Jogja Digital" (wawancara dengan Reren Indranila, Pimred Radar Jogja Digital, tanggal 10 Agustus 2020). 
Dari penjelasan tersebut, diketahui model penyajian news podcast adalah membacakan berita yang menjadi headline, dan berita ini juga dipublikasikan melalui surat kabar harian Radar Jogja Jawa Pos dan portal berita www.radarjogja.jawapos.com. Dari penjelasan tersebut diketahui bahwa selain konvergensi newsroom, konvergensi kontinum berupa cloning juga dilakukan pada podcast Radar Jogja Digital yaitu dengan memuat ulang berita yang diambil dari portal berita Radar Jogja Digital (radarjogja.jawapos.com) menjadi berita pada podcast news, meskipun dengan penyajian berbeda, namun konten sama, yaitu disajikan dengan membacakan headline berita dan isi beritanya.

Konvergensi newsroom antara podcast Radar Jogja Digital dengan media sosial juga dilakukan. Radar Jogja Digital memiliki platform media sosial yaitu twitter, instagram dan Facebook untuk publikasi berita dibawah satu newsroom yaitu Radar Jogja Digital. Creative and Production Devision Leader, Nanang Febriyanto (wawancara tanggal 10 Agustus 2020) menyebut twitter digunakan lebih sebagai media buzzer baik berita pada portal berita (www.radarjogja.jawapos.com. ataupun radar jogja.co yang saat ini sedang dinonaktifkan) maupun konten podcast. Sedangkan Instagram digunakan untuk publikasi berita dalam bentuk video, foto dan infografis. Instagram juga digunakan untuk media buzzer bagi konten podcast pilihan, misalnya beberapa episode podcast bias (bincang santai) dengan memanfaatkan fitur instagram stories. Sementara Facebook selain digunakan untuk media buzzer juga sebagai publikasi berita dan konten lain termasuk publikasi konten podcast (akan dijelaskan pada pembahasan konvergensi konten). Newsroom media sosial dan podcast untuk kebutuhan media buzzer dan publikasi berita menjadi satu newsroom yaitu di newsroom Radar Jogja Digital.

Pengamatan dilakukan peneliti untuk triangulasi data dengan mengamati twitter, instagram, Facebook dan podcast Radar Jogja Digital. Hasil pengamatan, pada twitter @ radarjogja digunakan lebih untuk media buzzer berita dan promo program podcast. Sedangkan Facebook Radar Jogja digunakan untuk publikasi berita dan media buzzer termasuk promo program podcast. Sedangkan instagram @ radarjogja, untuk instagram feed lebih digunakan untuk publikasi berita, sedangkan media buzzer menggunakan instagram stories, termasuk untuk buzzer promo podcast. Sementara pengamatan pada podcast Radar Jogja Digital, pada deskripsi podcast Radar Jogja Digital juga dijadikan media buzzer untuk promo portal berita dan media sosial. Dengan demikian dapat dipahami bahwa konvergensi kontinum Cross-Promotion juga diterapkan oleh media Radar Jogja Digital, baik media sosial maupun podcast.

Newsroom podcast Radar Jogja Digital terkonvergensi dalam newsroom dan struktur organisasi Radar Jogja Digital. Dari pembahasan tersebut, maka dapat dipahami bahwa newsroom podcast Radar Jogja Digital terkonvergensi dengan newsroom Radar Jogja Digital, platform media sosial, dan Radar Jogja Harian Cetak (meski tidak secara langsung). Alur konvergensi newsroom pada podcast Radar Jogja Digital dapat diamati pada gambar 1 (garis biru). 


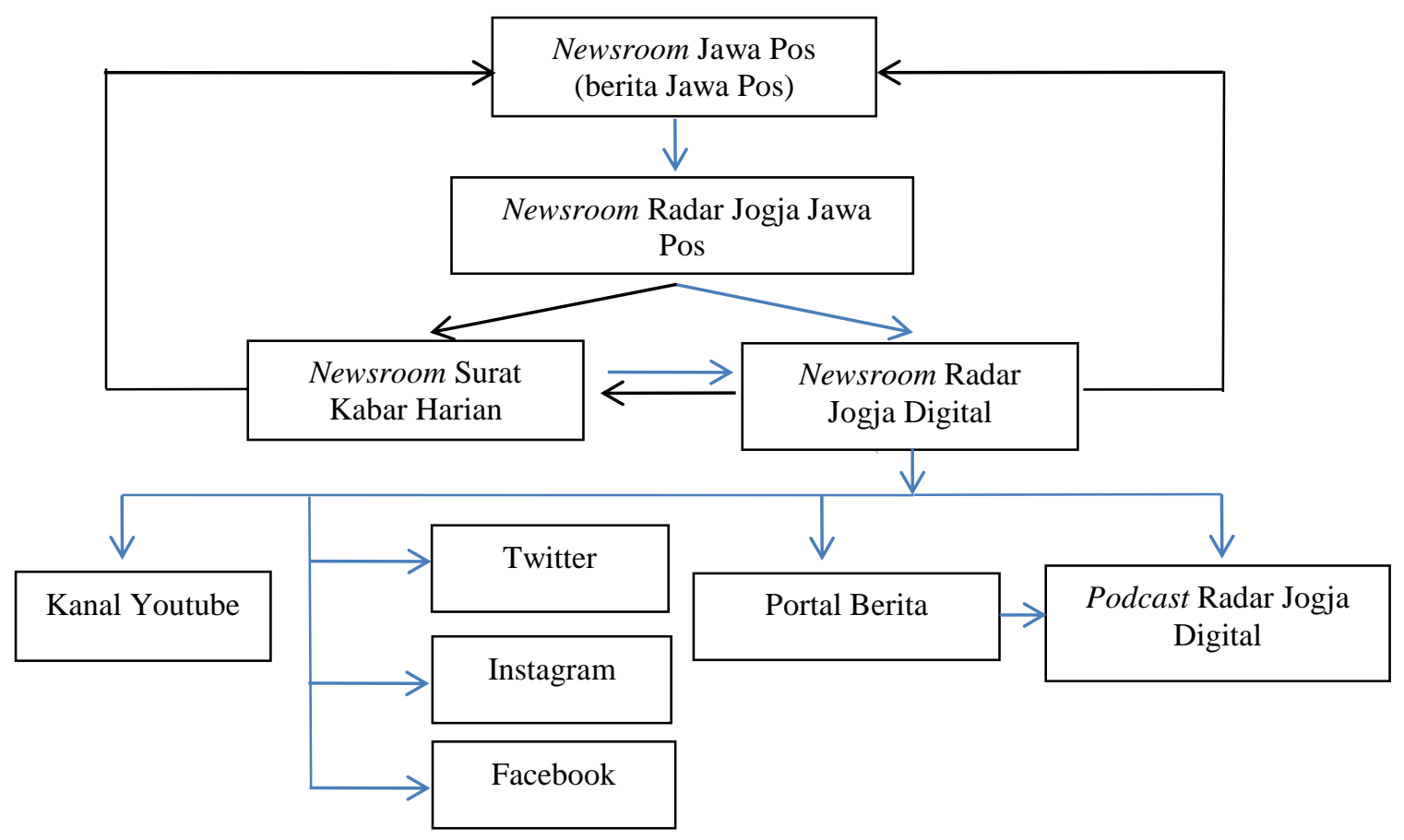

Gambar 1. Bagan Model Konvergensi Newsroom pada Podcast Radar Jogja Digital

\section{b) Konvergensi News Gathering}

Proses pencarian berita/peliputan (news gathering) sebenarnya sudah terpisah antara tim peliputan Radar Jogja Cetak dengan Radar Jogja Digital. Artinya pembagian tugas peliputan untuk masing-masing berita sudah terpisah, untuk memenuhi kebutuhan berita masing-masing, termasuk kebutuhan konten-konten podcast Radar Jogja Digital. Namun demikian kebutuhan podcast news yang diambil dari portal berita secara tidak langsung juga merupakan bentuk konvergensi news gathering, yaitu berita-berita yang dihasilkan melalui peliputan (news gathering) oleh tim Radar Jogja cetak masuk dalam newsroom radar jogja cetak yang kemudian diunggah di portal berita selanjutnya digunakan untuk podcast news. Jadi model konvergensi news gathering yang dilakukan bukan konvergensi news gathering secara langsung dimana tim peliputan radar jogja cetak wajib melakukan peliputan untuk kebutuhan podcast Radar Jogja Digital, namun lebih pada hasil peliputan yang ada digunakan untuk konten podcast news.

Disisi lain untuk lingkup tertentu yang membutuhkan data dari peliputan tim Radar Jogja Cetak, memungkinkan bagi tim Radar Jogja Digital untuk bekerjasama, meski tidak secara langsung. Sebagai contoh, untuk kebutuhan podcast Mainbola, Pemimpin Redaksi yang sekaligus host Podcast Radar Jogja Digital mengundang jurnalis dari desk olahraga (bagian dari redaksi Radar Jogja Cetak) sebagai narasumber untuk konten yang diangkat dalam podcast yaitu menceritakan hasil peliputan seputar bola dari sudut pandang dan cerita jurnalis tersebut. Format penyajian berupa obrolan santai pada podcast (wawancara dengan Reren Indranila, Pimred Radar Jogja Digital, 10 Agustus 2021).

Dari contoh tersebut, dapat diketahui model konvergensi news gathering pada podcast Radar Jogja Digital yaitu mengambil jurnalis Radar Jogja Cetak yang melakukan peliputan untuk menjadi narasumber dan menjelaskan topik/tema/materi dari peliputan jurnalis, kemudian dibuat konten podcast dengan penyajian dan penggalian sudut pandang yang berbeda. Inilah salah satu upaya bentuk kreativitas yang dilakukan oleh Radar Jogja Digital, terutama Podcast Radar Jogja Digital dalam news gathering untuk konten podcast. Podcast menyuguhkan tema yang berkaitan namun dari sudut pandang, cerita dan format penyajian yang berbeda. 
Begitu pula podcast lifestyle (wawancara dengan Reren Indranila, Pimred Radar Jogja Digital, 10 Agustus 2021) yang berisi informasi seputar gaya hidup yang dikemas dalam bentuk obrolan santai. Narasumber yang dihadirkan sementara ini adalah tim produksi Radar Jogja, baik Radar Jogja Digital maupun Radar Jogja Cetak.

Konvergensi news gathering untuk kebutuhan podcast Radar Jogja Digital juga terjadi ketika reporter Radar Jogja Online menjadi narasumber untuk konten podcast news pada awal episode podcast news. Model konvergensi news gathering yang terjadi adalah menghadirkan jurnalisjurnalis yang melakukan peliputan dalam podcast untuk menjadi narasumber, dengan menceritakan pandangan, dan perspektif yang berbeda tentang sebuah materi peliputannya.

Jika ditinjau dengan model konvergensi kontinum pada tahap coopetition pada podcast Radar Jogja Digital dengan platform lain adalah lebih pada bekerjasama, kompetisi tidak terlalu muncul karena tim dalam Radar Jogja Digital adalah sama, namun lebih pada saling mendukung untuk masing-masing platform misalnya dengan pembagian materi dan pembedaan konsep penyajian pada masing-masing platform. Sebagai contoh platform instagram menyuguhkan berita foto, infografis dan video hardnews durasi pendek, sedang podcast selain berita hard news yang dibacakan juga lebih ke sisi lain berita dengan penyajian talks/obrolan/diskusi. Hal ini disebabkan keterbatasan sumber daya manusia tim produksi pada media online Radar Jogja Digital. Alur konvergensi news gathering dapat diamati pada gambar 2 (garis biru).

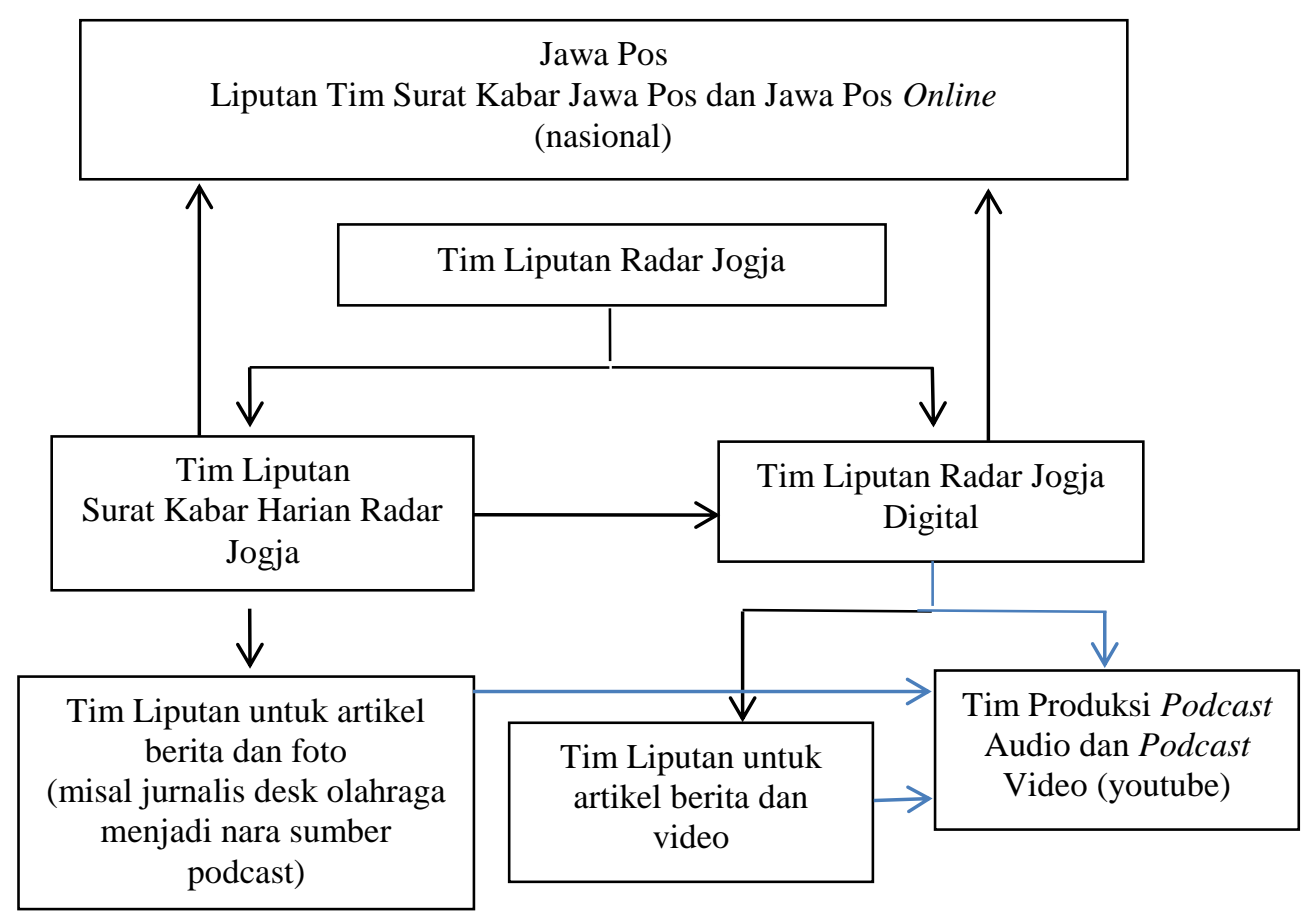

Gambar 2. Bagan Model Konvergensi News Gathering pada Podcast Radar Jogja Digital

c) Konvergensi Konten

Model konten berita pada podcast Radar Jogja Digital dapat dikategorikan menjadi dua, yaitu: 1) berita (news), berisi berita-berita hardnews pada podcast news yang menyuguhkan berita-berita headline, 2) konten berita lain yang bersifat soft news yang mengandung informasi namun dikemas dalam bentuk talk atau obrolan yaitu podcast bias, podcast lifestyle dan podcast mainbola. Untuk kebutuhan konten podcast news, model konvergensi konten podcast Radar Jogja Digital adalah dengan mengambil konten dari portal berita www.radarjogja.jawapos.com.. Hal ini juga sangat 
berkaitan erat dengan konvergensi newsroom pada Redaksi Radar Jogja Digital dan Radar Jogja Cetak.

Sedangkan untuk kebutuhan podcast dalam format penyajian talk seperti podcast bias, podcast lifestyle dan podcast mainbola, lebih pada menghadirkan narasumber dari tim peliputan media cetak harian, tim peliputan radar jogja online dan nara sumber dari luar.

Konvergensi kontinum pada level content sharing menurut Dailey, Demo dan Spillman ditandai dengan pertemuan rutin tim Radar Jogja Digital untuk bertukar ide dan tema oleh masingmasing anggota dan mendistribusikannya ke tiap platform. Dari wawancara dengan Reren, dalam newsroom Radar Jogja Digital hal tersebut telah dilakukan untuk kebutuhan platform digital, namun khusus untuk podcast, kadang produksi konten seringkali masih bersifat belum terencana/terkonsep dengan baik.

"Kalo podcast kadang ide muncul begitu saja lalu mengajak temen-temen untuk bikin konten podcast ngobrol bahas topik yang sedang tren, tapi produksi podcast saat ini juga belum bisa kontinu karena SDM dan situasi pandemic covid 19 ini. Tapi kalau ada konten podcast yang dengan menghadirkan nara sumber dari luar biasanya untuk podcast Bias ya dipersiapkan dengan baik apalagi kalau bagian dari program marketing". (wawancara dengan Pimred Radar Jogja Digital, Reren Indranila, 10 Agustus 2020).

Content sharing pada podcast Radar Jogja Digital lebih pada menghadirkan narasumber dari jurnalis Radar Jogja cetak maupun atau Radar Jogja online untuk membahas topik namun dilihat dari sisi lain dan disajikan dengan konsep berbeda yaitu talks. Konvergensi konten podcast tidak hanya mengambil konten dari platform lain dalam lingkup newsroom Radar Jogja Digital, tetapi hasil program podcast juga dipublikasikan melalui platform lain yaitu youtube dan Facebook. Sebagai contoh konten podcast dipublikasikan di media sosial Facebook, baik podcast dalam format audio atau video. Program podcast Radar Jogja Digital diproduksi dalam format audio untuk publikasi di sejumlah platform podcasting. Konten podcast Radar Jogja Digital juga diproduksi dalam format video yang dipublikasikan di kanal youtube Radar Jogja Channel yaitu khusus podcast Bias.

Sementara media sosial Facebook bukan sekedar menjadi media buzzer bagi podcast Radar Jogja Digital dengan berbagi link podcast atau kanal youtube seperti yang diterapkan pada media sosial twitter, namun juga menjadi media publikasi konten podcast. Seperti disampaikan oleh Reren (wawancara tgl 11 Agustus 2020) beberapa podcast Bias yang diproduksi pada masa sebelum dan saat pandemi covid 19 tidak hanya diunggah di platform podcast dan youtube namun juga media sosial Facebook. Diunggah di youtube karena podcast Bias merupakan program unggulan yang dijual untuk pemasaran. Hal tersebut juga disampaikan oleh Nanang Febriyanto (Creative and Production Devision Leader, wawancara tanggal 10 Agustus 2020) bahwa Facebook tidak hanya digunakan untuk media buzzer saja, namun memungkinkan mengunggah konten podcast untuk mengejar target audiens Facebook. Peneliti melakukan trianggulasi data pada Facebook Radar Jogja, dan kanal youtube Radar Jogja Channel, peneliti menemukan konvergensi konten podcast memang dilakukan pada platform Facebook dan youtube untuk publikasi konten podcast khususnya program podcast Bias, sebagai bagian dari program yang dijual untuk pemasaran dengan menghadirkan narasumber dari luar tim Radar Jogja Digital dan pembahasan konten juga tentang narasumber/lembaga terkait.

Dari pembahasan tersebut dapat dipahami bahwa model konvergensi konten podcast Radar Jogja Digital menggunakan multiplatform yaitu podcast, kanal youtube dan media sosial Facebook. Pembahasan tersebut dapat dipahami bahwa konvergensi kontinum tahap cloning juga terjadi ketika konten podcast baik format audio atau video diunggah kembali dalam media sosial Facebook. Alur konvergensi konten podcast Radar Jogja Digital, pada gambar 3 (garis biru). 


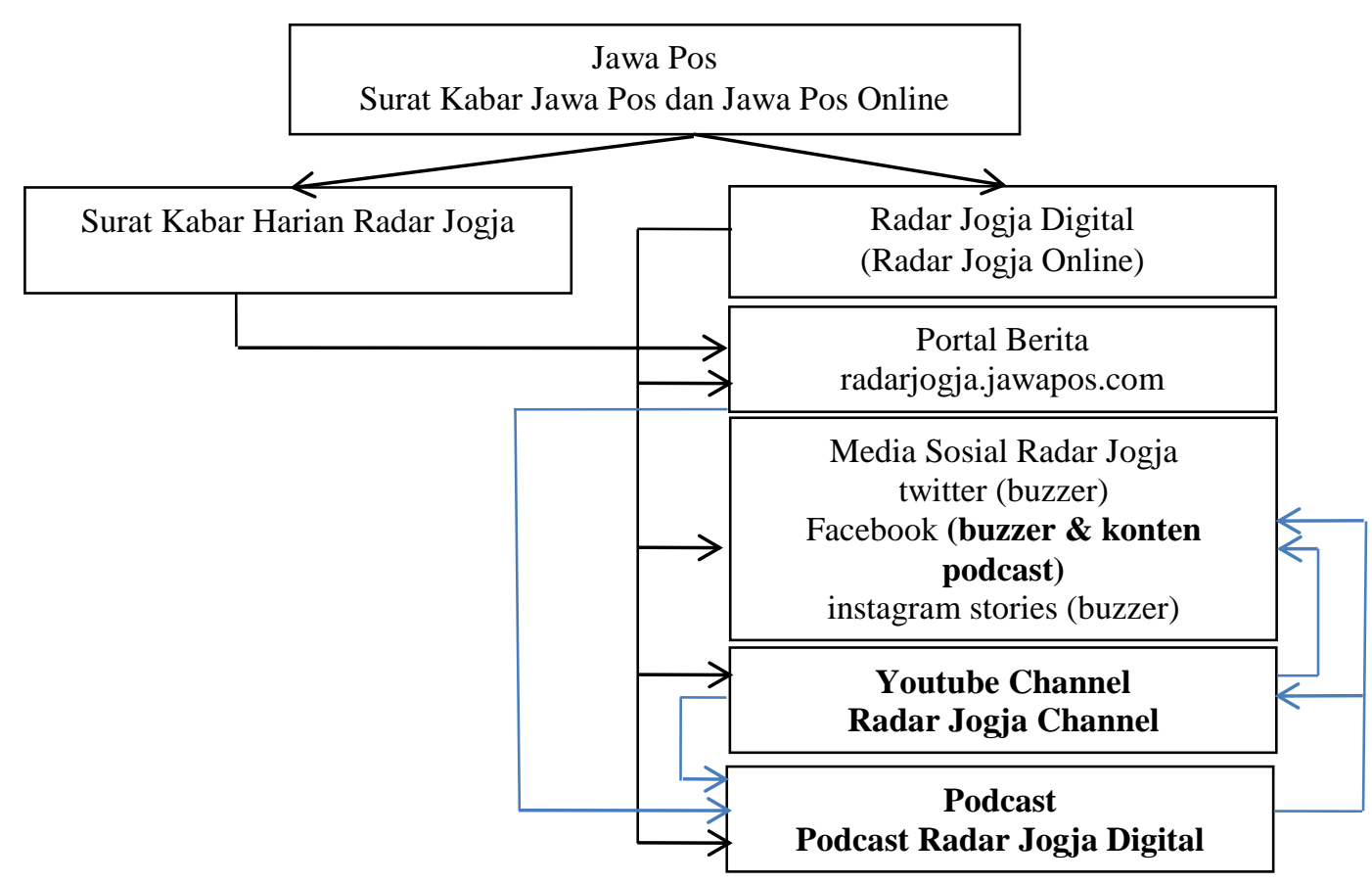

Gambar 3. Bagan Model Konvergensi Konten pada Podcast Radar Jogja Digital

Dari pembahasan tersebut dipahami bahwa Podcast Radar Jogja Digital menerapkan konvergensi jurnalistik meliputi konvergensi newsroom, konvergensi news gathering dan konvergensi konten. Selain itu juga menerapkan konvergensi kontinum pada tahap CrossPromotion, Cloning, Coopetition, Content Sharing. Sedangkan untuk level Full Coverage belum sepenuhnya dilaksanakan. Jika dilihat dari pendekatan hubungan antara media dan redaksi Radar Jogja Cetak dan Radar Jogja Digital, bisa dikatakan sudah full coverage, karena media cetak dan digital masing-masing telah memiliki editor, manajer, dan tim untuk mengelola pembagian proses perencanaan berita (story planning). Tetapi jika dilihat ke dalam media online Radar Jogja Digital belum sepenuhnya full coverage karena tim produksi masih sama artinya masing-masing platform untuk portal berita, youtube, podcast dan media sosial belum memiliki editor atau manajer untuk mengelola pembagian proses perencanaan berita (story planning) sehingga dapat dikatakan belum sampai pada level full coverage. Hal ini disebabkan keterbatasan sumber daya manusia. Pada podcast Radar Jogja Digital, pemimpin redaksi media online Radar Jogja Digital sekaligus menjadi pemimpin redaksi podcast dan juga host serta penentu konten podcast.

Pada tahap full coverage, memperbolehkan manajer bersama untuk menentukan kekuatan masing-masing media yang digunakan, untuk memberikan cerita yang paling bermakna bagi penonton dan membetuk tim yang terdiri dari anggota tiap platform untuk meliput berita dan mengolahnya. Pada tahap full coverage, media yang bekerja sama menghasilkan konten dan topik secara kolaboratif dengan memanfaatkan kekuatan platform media masing-masing. Upaya penguatan media dengan memanfaatkan sejumlah platform sudah mulai dilakukan termasuk mengembangkan podcast Radar Jogja Digital. Tetapi karena keterbatasan sumber daya manusia maka tim produksi konten podcast masih satu tim dengan tim Radar Jogja Digital, dengan kata lain podcast Radar Jogja Digital belum memiliki tim produksi khusus yang fokus untuk produksi dan pengembangan podcast. 


\title{
3.2. Podcast sebagai Strategi Perluasan Segmentasi Audiens Radar Jogja
}

Radar Jogja sebagai media cetak surat kabar harian memiliki target audiens masyarakat Yogyakarta dan sekitarnya. Koran harian Radar Jogja dalam publikasinya menjadi satu dengan Jawa Pos (yang diterbitkan pada skala nasional). Target audiens dari aspek pendidikan adalah setingkat mahasiswa dan pekerja. Sedangkan dari sisi usia, target audiensnya pada rentang usia 1860 tahun. Sementara untuk media online Radar Jogja Digital memiliki segmentasi dengan rentang usia 18-40 tahun. Termasuk segmentasi audiens yang ditargetkan untuk platform podcast Radar Jogja Digital juga 18-40 tahun.

Pemimpin Redaksi Radar Jogja Digital, Reren Indranila mengatakan:

\begin{abstract}
"Kami ingin mengejar segmentasi audiens kaum milenial, karena mereka adalah generasi mendatang. Oleh karena itu, kita harus menyesuaikan dengan selera mereka, termasuk berkembangnya podcast ini" (wawancara tanggal 10 Agustus 2020).
\end{abstract}

Hal yang sama disampaikan oleh Creative and Production Devision Leader, Nanang Febriyanto yang mengatakan:

"Kalau audiens yang sudah dewasa, pasti kedepannya akan hilang dengan berjalannya usia dan waktu. Oleh karena itu, kita harus mengejar generasi yang akan datang sebagai konsumen dan pembaca, ya generasi milenial. Mereka sudah tidak membaca koran, mereka megangnya handphone". (wawancara tanggal 10 Agustus 2020).

Tren podcast yang terus meningkat, menjadi salah satu motivasi dan alasan bagi Radar Jogja Digital untuk memperluas segmentasi audiens dengan target sasaran generasi milenial. Menurut Reren, melalui platform podcast, Radar Jogja Digital mencoba masuk ke kalangan milenial, meskipun saat ini jumlah listener podcast untuk wilayah Yogyakarta masih sedikit.

Podcast Radar Jogja Digital merupakan salah satu strategi untuk memperluas segmentasi audiens Radar Jogja Digital yang sebelumnya adalah pembaca berita cetak, sebagaimana sebelumnya bahwa Radar Jogja Digital merupakan surat kabar harian mainstream. Melalui podcast Radar Jogja, berusaha mengenalkan Radar Jogja ke kalangan milenial, yang mungkin saat ini sudah tidak membaca surat kabar. Reren mengatakan, podcast Radar Jogja tidak kemudian hanya menyuguhkan podcast berita saja namun juga podcast dengan topik lain, yang mudah diterima audiens milenial. Hal sama disampaikan oleh Nanang Febriyanto.

"Kami ingin kaum milenial mengenal dan tau Radar Jogja. Meski melalui konten podcast yang bukan news, misalnya konten podcast cerita misteri. Dari mereka suka dengerin cerita misteri di podcast Radar Jogja Digital, kemudian mereka akan kenal dengan nama Radar Jogja. Yang penting mereka tau dulu Radar Jogja, baru nanti harapannya mereka kemudian akan tau bahwa Radar Jogja itu adalah media berita, dan kita juga memiliki platform berita termasuk media cetak surat kabar harian. Oleh karena itu kami tidak hanya menyuguhkan konten pocdcast berita saja, namun konten lain yang kira-kira mudah diterima oleh masyarakat, termasuk generasi milenial " (wawancara dengan Creative and Production Devision Leader, Nanang Febriyanto, 10 Agustus 2020).

Menurut Reren, setiap platform pasti memiliki audiens masing-masing. Oleh karena itu, Radar Jogja Digital mencoba hal-hal baru termasuk podcast. Senada dengan Nanang yang mengatakan bahwa:

"Kami tidak ingin ketinggalan audiens di masing-masing platform" (wawancara tanggal 10 Agustus 2020).

Data pendengar podcast Radar Jogja Digital dari data analitik Anchor dan Spotify hasil wawancara dengan Pimred Radar Jogja Digital, diketahui total playlist per 13 Agustus 2020 sebanyak 3.109 (tiga ribu seratus sembilan) pendengar. Menurut Reren, hal ini cukup baik karena podcast Radar Jogja Digital tergolong masih sangat baru (wawancara tanggal 13 Agustus 2020). 
Dari jumlah pendengar podcast Radar Jogja Digital tersebut, diketahui bahwa data per 13 Agustus 2020, jumlah pendengar dari sisi usia tertinggi pada usia 23-27 tahun, peringkat kedua usia 28-34 tahun, peringkat ketiga usia 18-22 tahun, peringkat keempat usia 35-44 tahun, peringkat kelima usia dibawah 17 tahun, peringkat keenam 45-59 tahun, dan usia 60 tahun keatas tidak ada pendengar podcast. Sementara jika dilihat dari jenis kelamin, jumlah pendengar laki-laki lebih banyak daripada jumlah pendengar perempuan. Laki-laki sebesar lima puluh lima persen, perempuan tiga puluh persen, non specified sebesar tiga belas persen, dan non binary sebesar dua persen.

Data pendengar podcast Radar Jogja Digital saat ini bukan hanya masyarakat Jogja dan sekitarnya, namun semakin luas. Data analitik Spotify yang diperoleh dari wawancara dengan pemimpin redaksi Radar Jogja Digital diketahui bahwa secara geografis, pendengar paling banyak justru bukan dari wilayah Yogyakarta, namun Jawa Timur yaitu dua pulih tujuh persen, dan Jakarta sebesar dua puluh lima persen. Yogyakarta menduduki peringkat ketiga sebesar tiga belas persen, kemudian Jawa Barat dan Jawa Tengah sama sebesar yaitu sebelas persen. Selanjutnya Banten sebesar sebelas persen, Sumatera Utara sebesar satu persen dan Bali kurang dari satu persen. Data ini adalah data pendengar untuk wilayah Indonesia per 13 Agustus 2020. Pendengar podcast Radar Jogja Digital dari Indonesia sebesar delapan puluh tiga persen, sisanya dari negara lain yaitu Amerika sebesar empat belas persen, Brazil, Jerman, Singapura dan Swedia, dengan persentase masing-masing satu persen.

Podcast Radar Jogja Digital saat ini dipublikasikan dalam sejumlah platform dengan persentase pendengar yaitu Spotify sebanyak sembilan puluh satu persen, Anchor sebanyak tiga persen, Google Podcast sebanyak tiga persen, Apple Podcast sebanyak dua persen dan platform lainnya satu persen. Paling besar pendengar menggunakan Spotify artinya dari jumlah mayoritas pendengar berasal dari Indonesia dapat dikatakan paling besar menggunakan aplikasi Spotify untuk mendengarkan podcast.

Berdasar data-data analitik tersebut, dapat diketahui bahwa segmentasi audiens podcast Radar Jogja Digital berada pada rentang usia 18-34 tahun, artinya kelahiran mereka berada pada rentang tahun 1986 sampai dengan 2002 tahun. Generasi pada kelahiran ini yaitu tahun 1980-an sampai dengan 2000-an termasuk pada generasi milenial. Dapat dikatakan pula bahwa saat ini masyarakat di Indonesia terutama generasi milenial dan pada rentang usia 18-34 tahun mulai mengkonsumsi informasi menggunakan platform podcast. Dengan tren podcast saat ini yang terus meningkat, dapat memungkinkan pula meningkatknya pendengar podcast Radar Jogja Digital. Dari analisis tersebut, dapat dikatakan bahwa upaya Radar Jogja Digital untuk memperluas segmentasi audiens terutama kaum milenial telah terbukti menarik pendengar untuk mendengarkan podcast Radar Jogja Digital meski saat ini masih sebanyak 3000-an pendengar namun mampu memperluas segmentasi audiens. Perluasan segmentasi audiens juga terlihat dari geografi pendengarnya, bukan hanya dari kota lain namun juga negara lain. Hal ini justru menunjukkan bahwa media baru dalam hal ini platform podcast dapat digunakan untuk memperluas segmentasi audiens secara global, tidak terbatas geografi. Media baru dan internet memungkinkan bagi segmentasi audiens yang lebih luas untuk dapat mengakses konten podcast, dibandingkan Radar Jogja yang awalnya merupakan media massa cetak mainstream, yang publikasinya berupa surat kabar harian.

Mediamorfosis yang dilakukan media massa cetak dengan melakukan konvergensi media, dalam hal ini konvergensi konten, sebagai contoh adalah podcast Bias tidak hanya dipubikasikan melalui platform podcast audio saja namun dikemas dalam bentuk video yang juga dipublikasikan melalui kanal youtube Radar Jogja Digital dan Facebook. Konten podcast Bias tersebut juga dikonsumsi oleh audiens youtube. Jumlah subscriber kanal Youtube Radar Jogja Channel (per 5 Oktober 2020) sebanyak 43.900 (empat puluh tiga sembilan ratus). Sementara untuk viewer 
masing-masing episode podcast Bias bermacam-macam, ada yang dibawah seratus viewer, ada ratusan dan ada pula ribuan viewer. Bukan hanya penonton kanal youtube, konten podcast juga diunggah di media sosial Facebook, sehingga selain pendengar podcast dan penonton kanal youtube, maka follower Facebook juga dapat menikmati konten podcast. Dari analisis ini menunjukkan bahwa audiens podcast semakin luas dengan pemanfaatan media multiplatform sebagai bentuk mediamorfosis dan konvergensi media yang dilakukan oleh media cetak Radar Jogja Digital.

Dari pembahasan tersebut maka motivasi produksi konten pada podcast Radar Jogja sebagai upaya/strategi perluasan segmentasi audiens sangat bagus dan perlu dilakukan mengingat saat ini tren pendengar podcast terus meningkat baik dalam skala nasional maupun global. Sebagai langkah awal, keputusan Radar Jogja Digital untuk berani membuat konten podcast merupakan langkah yang baik sebagai upaya menarik audiens milenial sebagai regenerasi audiens dan memperkenalkan Radar Jogja. Hal ini terbukti dari data anilitik pendengar berdasar range usia menunjukkan pendengar paling banyak adalah generasi milenial. Selain itu dapat menjadi contoh bagi media cetak lain untuk dapat melakukan mediamorfosis dengan menerapkan konvergensi media, sehingga dapat memanfaatkan media baru untuk publikasi berita multiplatform.

Model konten podcast berita masih sebatas membacakan headline berita yang ada pada portal berita Radar Jogja Digital dan membuat konten talk/obrolan/diskusi dengan nara sumber jurnalis Radar Jogja atau narasumber lain. Sebagai langkah awal, hal tersebut dapat dipahami karena keterbatasan sumber daya manusia. Namun demikian untuk pengembangan podcast agar konten semakin baik dan konsisten, semakin banyak pendengar maka perlu memperhatikan beberapa hal diantarnya: 1) perencanaan konsep yang lebih matang dalam produksi konten termasuk pemilihan topik dan narasumber; 2) perlu memperhatikan variasi format berita, bukan hanya membacakan headline berita, namun juga dapat berupa format berita lain seperti feature, dokumenter, news bulletin atau news magazine yang disesuaikan dengan karakter audiens podcast; 3) perlu memperhatikan kontinuitas produksi dan publikasi konten podcast; 4) perlu lebih memperhatikan aspek produksi karena podcast merupakan produksi audio yang membutuhkan unsur artistik audio agar kemasan dan produk berita menjadi lebih menarik; dan 5) perlu penerapan standard operating procedure (SOP) produksi podcast berita yang disesuaikan dengan karakter produksi podcast baik podcast audio atau video. Dalam standard operating procedure produksi podcast berita tersebut mencakup tahapan-tahapan dan aspek-aspek yang perlu diperhatikan dalam proses produksi podcast berita disesuaikan dengan karakter podcast. Beberapa hal ini dapat dilakukan jika dalam podcast tersebut sudah memiliki sumber daya manusia yang cukup memadai berupa tim produksi dan tim kreatif yang fokus untuk produksi dan pengembangan podcast.

\section{PENUTUP}

Perkembangan teknologi memunculkan media baru yang berdampak bagi media massa. Media baru yang awalnya menjadi momok menakutkan karena gelombang media baru menggerus media massa konvensional. Tetapi disisi lain media baru justru menjadi media alternatif bagi media konvensional untuk mengembangkan berita dan publikasi berita dengan memanfaatkan banyak platform (multiplatform). Bahkan media massa cetak pun dapat memanfaat media baru untuk menghadirkan berbagai berita dalam berbagai format termasuk dalam format audio atau video.

Publikasi berita multiplatform pada media massa cetak dilakukan dengan menerapkan konvergensi media. Podcast Radar Jogja Digital, sebagai bagian dari media online Radar Jogja Digital telah menerapkan konvergensi media. Model konvergensi media yang diterapkan podcast Radar Jogja adalah konvergensi jurnalistik meliputi konvergensi newsroom, konvergensi news 
gathering dan konvergensi konten. Selain itu juga menerapkan konvergensi kontinum meliputi cross-promotion, cloning, coopetition, content sharing, selain itu mulai merambah ke level full coverage meskipun belum sepenuhnya.

Podcast Radar Jogja Digital menjadi salah satu platform yang digunakan untuk menarik audiens, yang targetnya adalah generasi milenial sebagai generasi saat ini dan mendatang. Podcast juga digunakan untuk memperluas segmentasi audiens baik dari sisi usia maupun geografi

Namun demikian, saat ini podcast Radar Jogja Digital belum begitu dikenal oleh masyarakat luas termasuk masyarakat Yogyakarta dan sekitarnya yang disebabkan oleh beberapa hal, diantaranya: 1) kebiasaan masyarakat dalam mengonsumsi berita, informasi atau konten belum banyak menggunakan podcast; 2) Sumber daya manusia yang dimiliki Radar Jogja Digital saat ini sangat minim sehingga konsentrasi untuk mengemas dan membuat konten podcast yang benarbenar terkonsep dengan matang belum dapat maksimal dilakukan; 3) masa pandemi covid 19 cukup berdampak bagi produksi podcast, karena tidak dapat maksimal dalam memproduksi konten podcast untuk menjaga kontinuitas publikasi podcast.

\section{Ucapan Terimakasih}

Terima kasih Saya ucapkan kepada Pemimpin Redaksi sekaligus Manajer Online Radar Jogja Digital, Creative dan Production Leader Radar Jogja Digital, Penerbit Jurnal, Editor, Reviewer serta teman-teman dan pihak-pihak yang telah membantu dan memberikan masukan dan saran hingga terselesaikannya penulisan artikel ilmiah ini.

\section{DAFTAR PUSTAKA}

APJII. (2019). Laporan Survei Penetrasi dan Profil Perilaku Pengguna Internet Indonesia 2018. https://apjii.or.id/content/read/104/418/BULETIN-APJII-EDISI-40---Mei-2019

Asyir, A. K., \& Nurbaya, S. (2019). Konvergensi Media dan Mediamorfosis : Strategi Digitalisasi Majalah Moeslim Choice dalam Proses Transformasi Basis Kerja. JSJ: Jurnal Studi Jurnalistik, 1(1), 52-67.

Creswell, J. W. (2012). Research design: pendekatan kualitatif, kuantitatif, dan mixed (S. Zuhri (ed.)). Pustaka Pelajar.

Fadilah, E., Yudhapramesti, P., \& Aristi, N. (2017). Podcast sebagai Alternatif Distribusi Konten Audio. Jurnal Kajian Jurnalisme, 1(1), 90-104. https://doi.org/10.24198/kj.v1i1.10562

Fidler, R. (2003). Mediamorfosis: Memahami Media Baru. Bentang Budaya.

Geoghegan, M., \& Klass, D. (2007). Podcast Sollution The Complete Guide to Audio and Video Podcast ing (2nd ed.). Apress.

Hennig, N. (2017). Why Podcast s? - ProQuest. $\quad$ 5-9. https://search.proquest.com/openview/876c1fed1b3e849de84fb398566462bc/1?pqorigsite=gscholar\&cbl=37743\%0Ainternal-pdf://0.0.1.190/1.html

Hidayat, A. (2020). Spotify Beri Trik Panen Cuan Bikin Podcast untuk Kreator Konten. Tempo.Co. https://bisnis.tempo.co/read/1351074/Spotify-beri-trik-panen-cuan-bikin-podcast -untuk-kreator-konten

Hidayat, M. A. (2018). Koran Legendaris Bernas Tutup Gara-Gara Tekor. Viva.Co.Id. https://www.viva.co.id/berita/nasional/1011631-koran-legendaris-bernas-tutup-gara-gara-tekor

Kurniawan, B. (2018). Harian Bernas Yogya Pamit "Pensiun." Detiknews.Com. https://news.detik.com/berita-jawa-tengah/d-3890633/harian-bernas-yogya-pamit-pensiun

Kusuma, S. (2016). POSISI MEDIA CETAK DI TENGAH PERKEMBANGAN MEDIA ONLINE DI INDONESIA. InterAct, 5, 56-71. http://ojs.atmajaya.ac.id/index.php/fiabikom/article/view/772

Madjid, A. (2014). Fenomenologi dan Hermeneutik: Perbandingan Dua Epistemologi. ETNOHISTORI: Jurnal Ilmiah Kebudayaan Dan Kesejarahan, 1(1), http://ejournal.unkhair.ac.id/index.php/etnohis/article/view/803

Meisyanti, \& Kencana, W. H. (2020). Platform Digital Siaran Suara Berbasis on Demand (Studi Deskriptif Podcast Di Indonesia). Jurnal Komunikasi Dan Media, 4(2), 191-207.

Moleong, L. (2004). Metodologi Penelitian Kualitatif. Remaja Rosda Karya. 
Nasrullah, R. (2016). Teori dan Riset Media Siber (Cybermedia) (1st ed.). Kencana.

Newman, N., \& Gallo, N. (2019). News Podcast s and the Opportunities for Publishers (Issue December). https://reutersinstitute.politics.ox.ac.uk/news-podcast s-and-opportunities-publishers

nielson.com. (2019). NIELSEN SIAP HADIRKAN TOTAL AUDIENCE MEASUREMENT. Nielson.Com. https://www.nielsen.com/id/id/press-releases/2019/nielsen-siap-hadirkan-total-audience-measurement/

Permana, F. Y. (2017). Mempertahankan Pasar Media Cetak Melalui Konten Augmented Reality / Ar. Channel, 5(2), 77-90.

PEW Research Center Journalism \& Media. (2019). Audio and Podcast ing Fact Sheet. Journalism.Org. https://www.journalism.org/fact-sheet/audio-and-podcast ing/

Prihartono, A. W. (2016). Surat Kabar \& Konvergensi Media (Studi Deskriptif Kualitatif Model Konvergensi Media Pada Solopos). CHANNEL: Jurnal Komunikasi, 4(1), 105-116. https://doi.org/10.12928/channel.v4i1.4210

Rahmad, M. (2013). Berakhirnya Media Cetak: Tempo Diambang Kebangkrutan? Kompasiana. https://www.kompasiana.com/mrahmad/552e47ac6ea83403398b4570/berakhirnya-media-cetak-tempodiambang-kebangkrutan

Robertson, J. (2019). How podcast $s$ went from unlistenable to unmissable. Bbc.Com. https://www.bbc.com/news/business-49279177

Sugiyono. (2006). Metode Penelitian Kuantitatif Kualitatif dam R\&D. Alfabeta.

Wahyuningsih, T., \& Zulhazmi, A. Z. (2020). Jurnalisme Era Baru (Konvergensi Media Radar Jogja Dalam Menghadapi Persaingan Media). Academic Journal of Da'wa and Communication, 1(1), 76. https://doi.org/10.22515/ajdc.v1i1.2412

Zaenudin, A. (2017). Hikayat Podcast . Tirto.Id. https://tirto.id/hikayat-podcast -cufm 